\title{
The Change of Bacterial Spectrum after Storage of $X$. campestris pv. campestris Inoculated Cabbage Heads (Brassica oleracea var. capitata L.)
}

\author{
Lucia Ragasová ${ }^{1}\left(\mathbb{D}\right.$, Eliška Peňázová ${ }^{2}$ (D) Filip Gazdík ${ }^{2}$, Jakub Pečenka ${ }^{2}$, Jana Čechová ${ }^{2}$, \\ Robert Pokluda ${ }^{1}\left(\mathbb{D}\right.$, Miroslav Baránek ${ }^{2}$, Dariusz Grzebelus ${ }^{2,3}$ (D) and Aleš Eichmeier ${ }^{2, *(\mathbb{D})}$ \\ 1 Department of Vegetable Growing and Floriculture, Faculty of Horticulture, Mendel University in Brno, \\ Valtická 337, 69144 Lednice, Czech Republic; lucia.ragasova@mendelu.cz (L.R.); \\ robert.pokluda@mendelu.cz (R.P.) \\ 2 Mendeleum - Institute of Genetics, Faculty of Horticulture, Mendel University in Brno, Valtická 337, \\ 69144 Lednice, Czech Republic; eliska.penazova@mendelu.cz (E.P.); filip.gazdik@mendelu.cz (F.G.); \\ jakub.pecenka@mendelu.cz (J.P.); jana.cechova@mendelu.cz (J.Č.); miroslav.baranek@mendelu.cz (M.B.); \\ d.grzebelus@ogr.ur.krakow.pl (D.G.) \\ 3 Department of Plant Biology and Biotechnology, Faculty of Biotechnology and Horticulture, \\ University of Agriculture in Krakow, 31425 Krakow, Poland \\ * Correspondence: ales.eichmeier@mendelu.cz; Tel.: +420-519367315
}

Received: 17 February 2020; Accepted: 22 March 2020; Published: 24 March 2020

\begin{abstract}
Changes in the bacterial spectrum of cabbage heads after storage under commonly used storage conditions were examined in this study. Cabbage seeds (Brassica oleracea var. capitata L.) were artificially inoculated with $X$. campestris pv. campestris (Xcc), a serious pathogen of cruciferous plants causing black rot. Isolation of bacterial cultures from Xcc-inoculated and non-inoculated cabbage heads were carried out in two time points - at the day of harvest and after four months of storage. According to our previous research and literature reports, the most frequent genera of bacteria were chosen for PCR testing, i.e., Bacillus cereus group, Bacillus subtilis group, Pseudomonas sp., and $X$. campestris pv. campestris. A few of the obtained bacterial cultures were negative for the four above-mentioned species. In those, other bacteria were identified by $16 \mathrm{~S}$ rRNA sequencing. In both Xcc-inoculated and non-inoculated cabbage heads, changes of the bacterial spectrum over time were observed. The severity of Xcc infection of heads increased after four months of storage. Bacillus species represented the most frequently occurring bacterial genus. The presence of the Bacillus subtilis group increased significantly after storage in non-inoculated cabbage heads. The minor part of the other genera identified by sequencing in the first sampling were not detected in the stored cabbage heads. This was associated with a possible antagonistic behavior of Pseudomonas sp. and Bacillus sp.
\end{abstract}

Keywords: black rot; sequencing; post-harvest; storage; vegetable; Pseudomonas; cabbage; Bacillus

\section{Introduction}

Bacterial soft rots are very important post-harvest diseases of many vegetable crops and cause great losses in stored vegetables [1,2]. Cabbage (Brassica oleracea var. capitata), an economically important crop, is susceptible to bacterial soft rot, caused by Pectobacterium carotovorum subsp. carotovorum [Erwinia carotovora] [3]. Besides Erwinia species, major causal agents of bacterial soft rots of cruciferous vegetables are various species of Pseudomonas, Bacillus, Lactobacillus and Xanthomonas campestris pv. campestris $[1,4]$. Generally, soft rot occurs in stored fleshy vegetables and it is spread worldwide. The estimated losses caused by bacterial soft rot in stored cabbage vary between 15-30\% of the harvested yield. The disease symptoms can be observed in the field, storage, or during transport and 
marketing [5]. Latent infection in harvested vegetables is not unusual and may cause serious damage upon storage, especially in poor transport and storage conditions with higher temperatures and high humidity [6]. Xanthomonas campestris pv. campestris (Xcc), the causal agent of black rot, is one of the most serious pathogens of cabbage and related cruciferous vegetables worldwide, particularly under warm and wet conditions [4]. Primary infection source of Xcc is plant debris, soil or seeds [7-10]. Secondary transmission of the pathogen from infected plants proceeds through cruciferous weeds, insects and agrotechnical procedures in the field supported by rain or sprinkler irrigation [9,11-13]. Pathogen enters the plant through hydathodes and wounds, and colonizes its vascular system, causing V-shaped chlorotic or necrotic lesions on leaf margins often with dark-colored veins. However, the symptoms are variable among the cruciferous species $[14,15]$. Heavily infected leaves of cabbage fall off and soft rot may occur caused by secondary invasion of Pseudomonas species or Erwinia species [15]. There is no effective chemical control for the bacteria causing bacterial soft rot [16]. Hot water treatment is recognized as a simple control technique [17]. However, it is associated with higher energy costs [18] and a low suppression effect was reported by some authors [19]. Chlorination using sodium or calcium hypochlorite can be applied as a preventive treatment, but its effectiveness is also limited and can damage the vegetables [20]. The use of proper packing material (e.g., alum, newspaper wrap) can reduce mechanical damage particularly during transport, thus decreasing the incidence and spread of bacterial soft rot pathogens [3]. According to several authors, the antagonistic behavior of Pseudomonas and Bacillus species against other bacterial genera has been presumed [21-23]. Antagonistic effects of Bacillus sp. against Xcc was reported by Wulff [24].

Many studies focused on the survival of Xcc in plant debris, in the field or on seeds [7-13,25-27]. The black rot disease quickly develops in warm, humid conditions and can spread rapidly by rain dispersal and irrigation [28]. Unveiling the persistence of $X_{c c}$ in $1-2{ }^{\circ} \mathrm{C}$, the usual storage temperature, is challenging. Currently, it has not been reported. Hence, the main aim of this study was (i) to describe the persistence of $X_{c c}$ in Xcc-inoculated cabbage heads during storage; (ii) to compare the spectrum of the most frequent bacterial genera of cultivable bacteria on cabbage heads inoculated and non-inoculated with $\mathrm{Xcc}_{\mathrm{cc}}$ and (iii) to measure the relative frequency of Bacillus and Pseudomonas species, as related to the presence of Xcc on inoculated cabbage heads.

\section{Material and Methods}

\subsection{Plant Material and Sampling}

The experiment was set up using head cabbage (Brassica oleracea var. capitata) cv. Avak (Moravoseed, Mikulov, Czech Republic) which is suitable for immediate consumption as well as for storage (Moravoseed, Mikulov, Czech Republic). Avak is an open-pollinated cultivar, very popular in the Czech Republic. It was selected based on our previous experience of showing the black rot symptoms in conditions suitable for Xcc reproduction. Approximately $0.2 \mathrm{~g}$ cabbage seeds were artificially inoculated with Xcc (isolate HRIW 3811, UK). The inoculation was performed by soaking seeds in a bacterial suspension containing approximately $10^{8} \mathrm{CFU} / \mathrm{mL}$ for two hours at room temperature, followed by drying seeds on the filter paper in a ventilation hood [29], as proposed previously [30]. In total, 60 seedlings, 30 Xcc-inoculated and 30 non-inoculated plants, were grown under controlled conditions in the growth chamber. At the stage of four true leaves, 20 plants from both groups were randomly selected. In total, 40 plants were transferred to the field (Lednice, Czech Republic, GPS 48.7999189N, 16.8033931E) on June 2017. The plants were cultivated using standard practices, the plants were optimally fertilized and irrigated. The isolation distance between Xcc-inoculated and non-inoculated plants was $30 \mathrm{~m}$, separated by cereals. The field was weeded manually. After three months of cultivation, cabbage heads were harvested by pulling and the roots were cut out in the laboratory with a sterile knife. The average head weight was $2.2 \mathrm{~kg}$ in both treatments.

The cabbage heads were stored in the storage hall at $1-2{ }^{\circ} \mathrm{C}$ and high humidity $(95 \% \mathrm{RH})$ controlled by an air conditioner, which is recommended for the storage of cabbage. The cabbage heads were 
stored in perforated plastic boxes. The treatments were put in different places in the storage hall to avoid cross-contamination. The sampling before storage was done in October 2017, at the day of harvest, and after four months of storage in February 2018. At both time points, 10 Xcc-inoculated and 10 non-inoculated cabbage heads were analyzed.

The weather conditions during the experiment were recorded by the weather station located in Faculty of Horticulture (Lednice, Czech Republic, GPS 48.791470, 16.801696). The station measures temperature three times per day ( 7 a.m., 2 p.m., 9 p.m.), relative humidity, hours of sunlight, soil temperature and amount of precipitation.

\subsection{Isolation of Bacteria From Cabbage Heads}

The presence of bacteria was evaluated in three different head parts: cabbage stalk, inner leaves and superficial leaves (Figure S1). From each part, three pieces of plant tissue $(4 \times 4 \mathrm{~mm})$ were disinfected in $2 \%$ sodium hypochlorite solution and washed twice in sterile distilled water according to Eichmeier et al. [31]. Tissue samples were placed on two different media, both supplemented with $0.05 \mathrm{~g} / \mathrm{L}$ cycloheximide (Biosynth, Staad, Switzerland) to avoid fungal contamination. One piece of tissue per dish was used. For the description of Xcc persistence in cabbage heads through storage and its possible elimination by naturally present antagonists, the semi-selective medium PXCAB (Phyto Xano Camp Agar Base, HIMEDIA ${ }^{\circledR}$, Mumbai, India) was used. The original medium was developed by Chang [32] for the isolation of Xanthomonas campestris which was then modified by lowering the $\mathrm{pH}$ of the medium using additional potassium dihydrogen phosphate. Bacterial composition and its changes after storage were evaluated on a non-selective medium MPA (Meat-Peptone Agar, Sigma-Aldrich, St. Louis, USA). All samples were cultivated at $25{ }^{\circ} \mathrm{C}$ in the dark and the growth of bacterial cultures was observed once a day. All cultures obtained from Petri dishes with MPA were re-cultivated to separate the present genera and identify them through PCR using genus-specific primers or through Sanger sequencing of the PCR amplicons.

\subsection{Detection of the Bacterial Group, PCR, and Sequencing}

The samples were tested by PCR using four primer pairs targeting the mot $B$ gene sequence of Bacillus cereus group, the gyrA gene of Bacillus subtilis group, the $16 \mathrm{~S}$ rRNA gene of Pseudomonas sp., and the hrpF gene of Xanthomonas campestris pv. campestris (Table 1).

Table 1. Specific primer pairs used for identification of the four targeted bacterial genera.

\begin{tabular}{|c|c|c|c|c|c|c|}
\hline Genus & Primer Pair & Sequence $5^{\prime}-3^{\prime}$ & $\begin{array}{c}\text { Product } \\
\text { Size }\end{array}$ & Gene & $\mathrm{AT}^{*}$ & Ref. \\
\hline \multirow{2}{*}{ Bacillus cereus group } & BCFomp1 & ATCGCCTCGTTGGATGACGA & \multirow{2}{*}{$575 \mathrm{pb}$} & \multirow{2}{*}{$m o t B$} & \multirow{2}{*}{$55^{\circ} \mathrm{C}$} & \multirow{2}{*}{ [33] } \\
\hline & BCRomp1 & CTGCATATCCTACCGCAGCTA & & & & \\
\hline \multirow{2}{*}{ Bacillus subtilis group } & gyrA-f & CAGTCAGGAAATGCGTACGTCCTT & \multirow{2}{*}{$1024 \mathrm{pb}$} & \multirow{2}{*}{ gyrA } & \multirow{2}{*}{$54^{\circ} \mathrm{C}$} & \multirow{2}{*}{ [34] } \\
\hline & gyrA-r & CAAGGTAATGCTCCAGGCATTGCT & & & & \\
\hline \multirow{2}{*}{ Pseudomonas sp. } & Pseudomonas_F & CTACGGGAGGCAGCAGTGG & \multirow{2}{*}{$150 \mathrm{pb}$} & \multirow{2}{*}{$\begin{array}{c}\text { 16S } \\
\text { rRNA }\end{array}$} & \multirow{2}{*}{$62{ }^{\circ} \mathrm{C}$} & \multirow{2}{*}{ [35] } \\
\hline & Pseudomonas_R & TCGGTAACGTCAAAACAGCAAAGT & & & & \\
\hline \multirow{2}{*}{$\begin{array}{c}\text { Xanthomonas campestris } \\
\text { pv. campestris }\end{array}$} & DLH 120 & CCGTAGCACTTAGTGCAATG & \multirow{2}{*}{$618 \mathrm{pb}$} & \multirow{2}{*}{ hrpF } & \multirow{2}{*}{$63^{\circ} \mathrm{C}$} & \multirow{2}{*}{ [36] } \\
\hline & DLH 125 & GCATTTCCATCGGTCACGATTG & & & & \\
\hline
\end{tabular}

In cases where none of the four targeted species was detected, DNA was extracted using $5 \mathrm{mg}$ of bacterial culture according to Roothie and Umesha [37]. The identity of isolates was determined by Sanger sequencing of the V3-V4 region of 16S rRNA [38], as described by Eichmeier et al. [31]. CLC Genomics Workbench 6.0 (CLC Bio, Aarhus, Denmark) was used to analyze the obtained sequences. The genus of bacteria was determined with similarities higher than $90 \%$ in GenBank/NCBI, as proposed by Klindworth et al. [38]. 


\subsection{Statistical Analysis}

PAST 3.03 [39] was used for the statistical analysis. Bray-Curtis distance was used as a metric of the similarity of bacterial species composition between samples. The effect of the sampling date, the Xcc inoculation and the head part were tested by one-way and two-way PERMANOVA using Bray-Curtis distances $(n=99,999)$. In all cases, differences at $p<0.05$ were considered as statistically significant.

The relation of bacteria presence/absence to (i) the sampling time point, (ii) inoculation with Xcc and (iii) the cabbage head part (cabbage stalk, inner leaves and superficial leaves) was analyzed by multivariable analysis, using Canoco 5 (Biometris, Wageningen University and Research centre, Wageningen, The Netherlands; University of South Bohemia in České Budějovice, České Budějovice, Czech Republic). Since the effect of the cabbage head part was not significant, this factor was excluded from subsequent analyses. Canonical correspondence was chosen as a statistical method [40]. Significance level was calculated by Monte-Carlo permutation test calculated by 999 permutations. The analyzed data comprised results from testing all three cabbage head parts, thus in each plant the bacteria genera were detected from 0 to 3 times.

\section{Results}

\subsection{Persistence of Xcc on Cabbage Heads after Storage}

In case of plants from Xcc-inoculated seeds, the presence of Xcc was confirmed in five heads (50\%) in the first sampling point. Four of these heads showed typical symptoms of the black rot, V-shaped lesions on superficial leaves or black veins. Xcc was also detected in one head from the non-inoculated control, although all control heads were symptomless with respect to the typical symptoms caused by Xcc. After four months of storage, the number of heads with Xcc increased to seven (70\%) within Xcc-inoculated plants and almost all of them showed the symptoms. Xcc was also detected on three heads (30\%) after storage (Table 2, Figure 1). Symptoms on the Xcc-inoculated and non-inoculated cabbage heads after storage are shown in Figures S2 and S3.

Table 2. Number of heads with positive X. campestris pv. campestris (Xcc) detection.

\begin{tabular}{ccc}
\hline & Before Storage & After Storage \\
\hline Xcc inoculated & 5 & 7 \\
\hline Non-inoculated & 1 & 3 \\
\hline
\end{tabular}

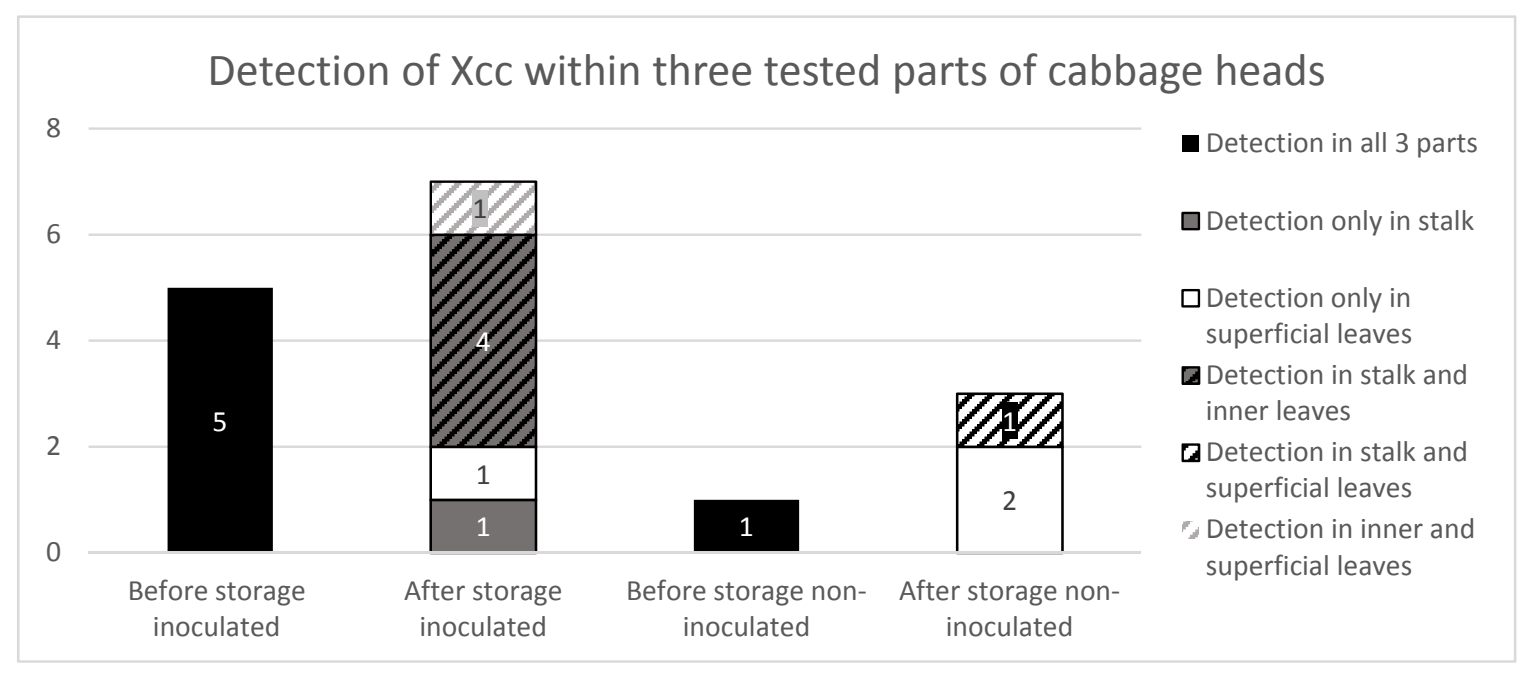

Figure 1. Detection of $X_{c c}$ within three parts of inoculated and non-inoculated cabbage heads at harvest and after storage. 
$X$. campestris pv. campestris was detected in all three parts of five Xcc-inoculated cabbage heads. However, in the stored cabbage heads the Xcc was not detected on all three parts of the seven Xcc-positive cabbage heads. After storage, Xcc was present mostly on stalks and inner leaves. Similarly, Xcc was detected on all three parts of one non-inoculated cabbage head before storage, while after storage was Xcc present on inner leaves of two heads on superficial leaves of one non-inoculated head (Table 2, Figure 1).

\subsection{Changes of Bacterial Spectra Present in Cabbage Heads Inoculated and Non-Inoculated with Xcc}

At harvest, Pseudomonas and Bacillus species were the genera with the highest occurrence. Pseudomonas sp. was present on all ten Xcc-inoculated heads and ten non-inoculated heads; while Bacillus cereus group was detected on eight non-inoculated heads. The minor bacterial genera, not detected using the PCR assay, were identified by sequencing as Acinetobacter, Chryseobacterium, and Enterobacter.

Two bacterial cultures from the sampling at the time of harvest of Xcc-inoculated heads and four from non-inoculated heads could not be identified, as they were with the most similar to undetermined bacteria in GenBank/NCBI (Figure 2).

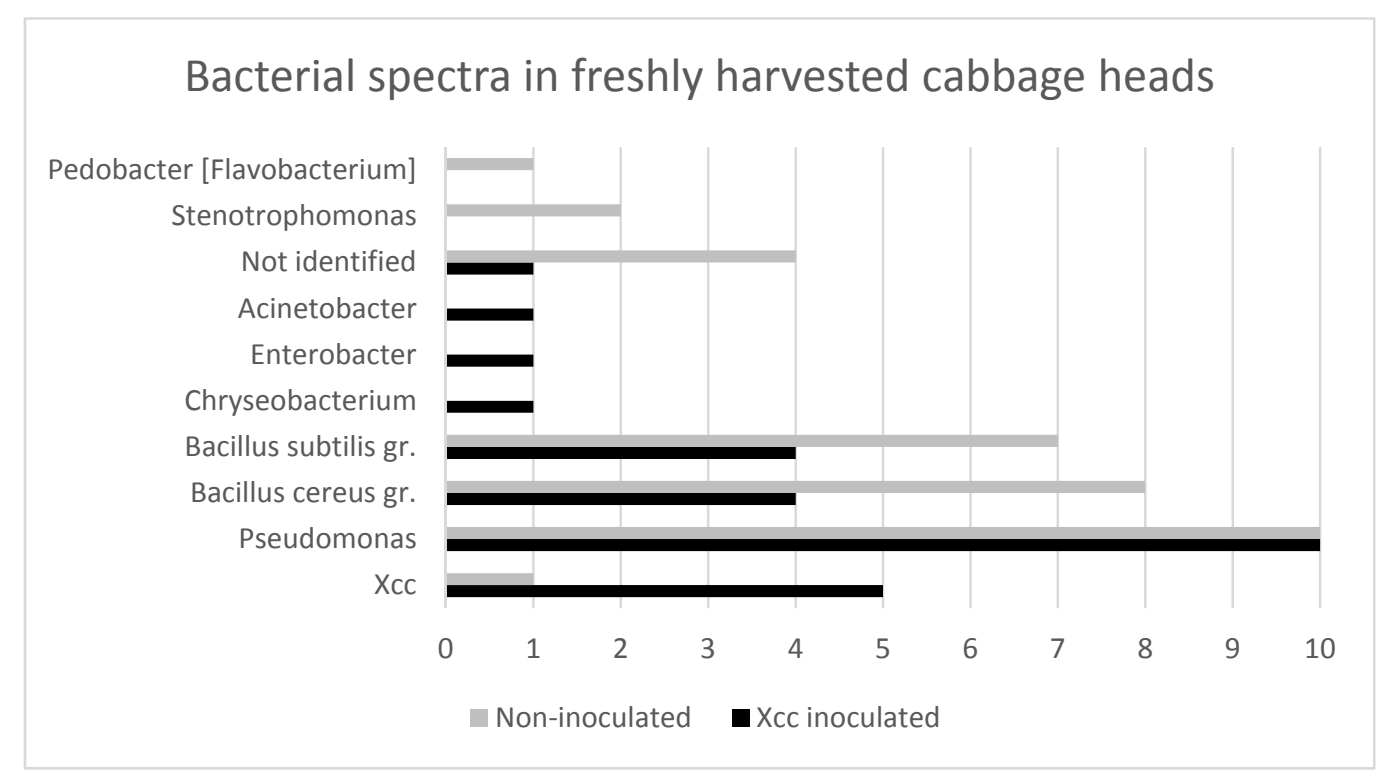

Figure 2. The number of cabbage heads from the sampling at the day of harvest of Xcc-inoculated and non-inoculated cabbage heads with positive detection of the bacterial genera.

After storage, no other bacterial genera besides four tested ones were present on cabbage heads. The Bacillus cereus group was detected only in one Xcc-inoculated cabbage head, however, its presence markedly decreased (Figure 3).

\subsection{Effect of Bacillus and Pseudomonas Species to Xcc Incidence}

The result of CCA (canonical correspondence analysis) indicates, that the occurrence of Xcc was the most frequent within Xcc-inoculated cabbage heads and even more prevalent in the stored heads (Figure 4). In contrast, the Bacillus subtilis group was present more often in non-inoculated heads. Pseudomonas species and the Bacillus cereus group were more often detected on freshly harvested heads. The analysis indicates a negative correlation between the presence of $X_{c c}$ and the Bacillus subtilis group. The mutual appearance of these genera within the three parts of cabbage heads was the least frequent. no correlation was found between Pseudomonas and Xcc or factors determining the relationship were not included in the analysis. Analyzed data and results summary: $\mathrm{DF}=2$; total variation is 0.90033 ; pseudo-F $=13.7 ; p=0.001$. 


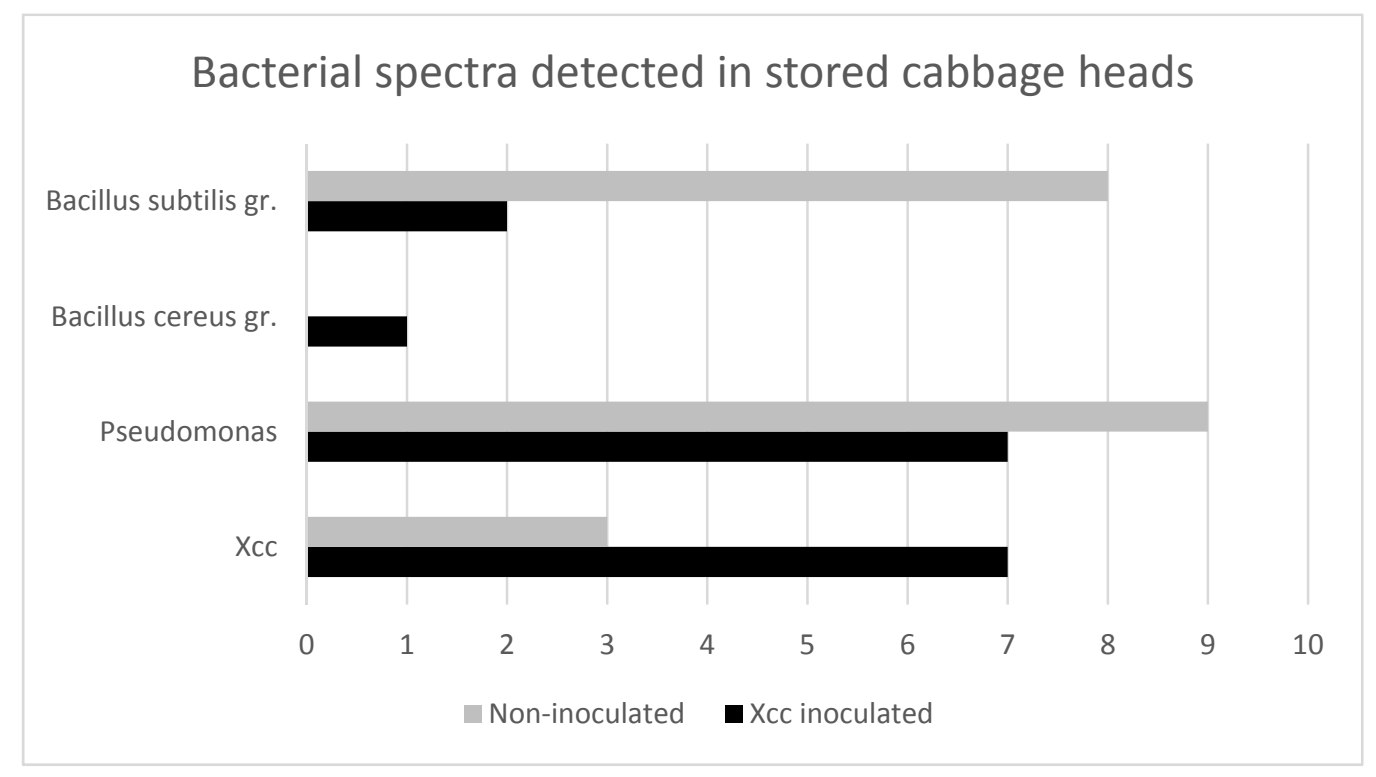

Figure 3. The number of cabbage heads from the sampling after storage of Xcc-inoculated and non-inoculated cabbage heads with positive detection of the bacterial genera.

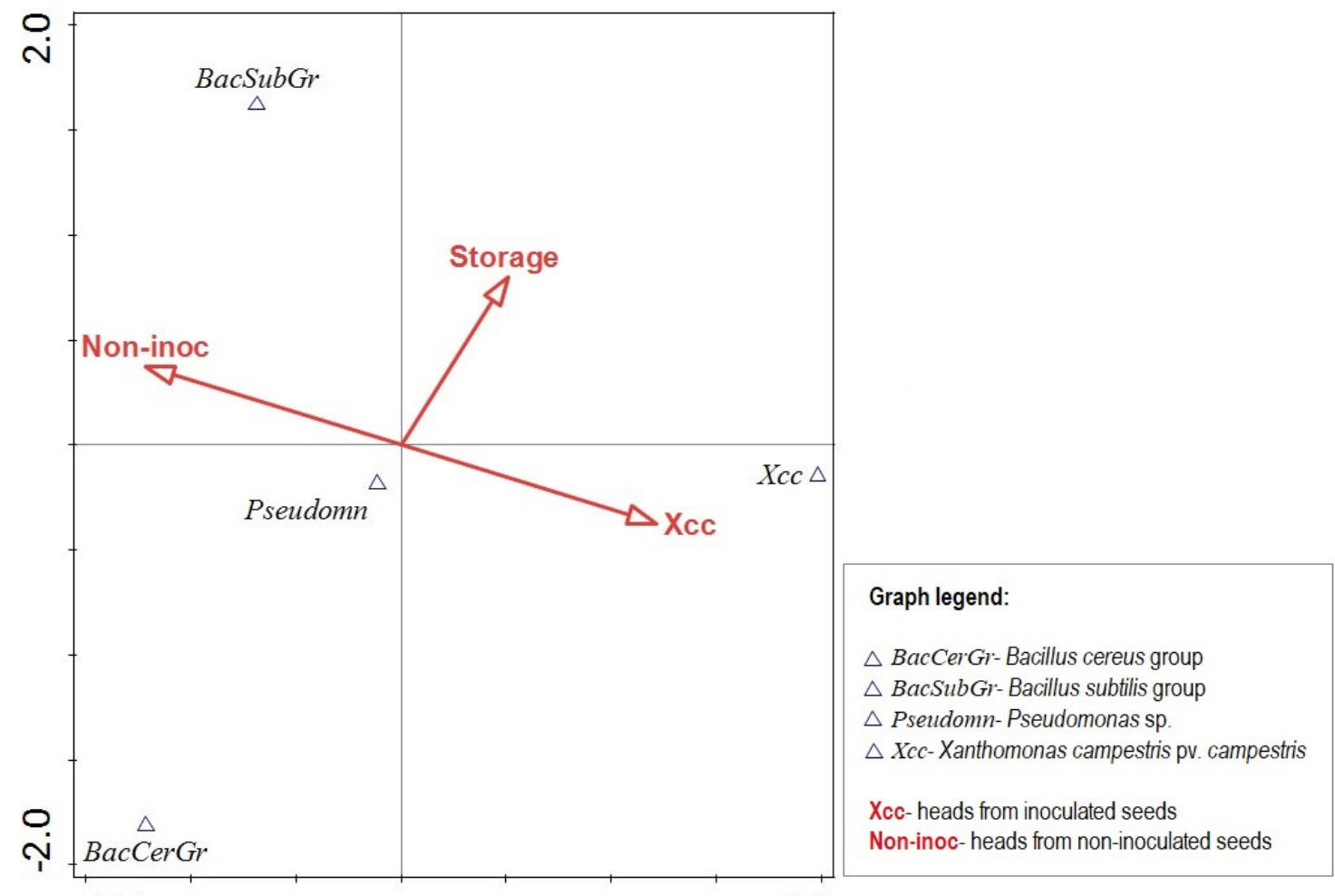

$-1.5$

2.0

Figure 4. CCA ordination diagram shows the relationships between the presence of the bacterial genera and two factors including the time point of sampling (at the harvest and after storage) and the artificial inoculation with Xcc.

PERMANOVA indicated that the presence of bacteria is significantly determined by the date of sampling $(p=0.00009)$ and inoculation with Xcc $(p=0.00005)$. Sampling different head parts did not affect the composition of the bacterial spectrum significantly ( $p=0.7577)$. Two-way PERMANOVA showed that the sampling date and inoculation with Xcc were significant (both $p=0.00001$ ), while their interaction was not. 


\section{Discussion}

\subsection{Persistence of Xcc on Cabbage Heads during Storage and Potential Antagonistic Effect of Bacillus Species}

The optimal growth temperature for X. campestris pv. campestris varies between $25-30{ }^{\circ} \mathrm{C}$ and spreading of the pathogen is strongly facilitated by humid and wet conditions (e.g., heavy rains, overhead irrigation) [4,41,42]. During summer months (June, July, and August) of 2017 in Lednice, $58 \%$ of the days reached maximum daily temperatures above $28^{\circ} \mathrm{C}$ and average relative humidity from May to September was low (38\%). Such weather conditions were not favorable to the development of black rot symptoms even on plants produced from artificially Xcc-inoculated seeds [28].

Despite the fact that the growth-limiting temperature for $\mathrm{Xcc}_{\mathrm{c}}$ was estimated as $5{ }^{\circ} \mathrm{C}$, the increase of Xcc occurrence after storage was observed in this study [42]. On Xcc-inoculated cabbage heads, Xcc presence was higher on cabbage stalks and inner leaves, while on non-inoculated heads the infection on superficial leaves was more frequent and no infection was detected on inner leaves. These findings suggest that inoculation with Xcc was successful, while some cabbage heads from non-inoculated seeds were naturally infected in the field and Xcc symptoms developed from the inside during the post-harvest period.

The negative correlation between the presence of X. campestris pv. campestris and Bacillus subtilis group indicates antagonistic potential of the latter microorganism. Such a behavior was reported for some isolates of naturally occurring epiphytic non-pathogenic bacteria (Bacillus species and Pseudomonas fluorescens) against X. axonopodis pv. phaseoli [43] or X. campestris pv. campestris [24]. However, to support this statement, detailed research focused on species identification of Bacillus genera is necessary. Besides, various species of Pseudomonas and Bacillus are also causal agents of soft rot [5].

\subsection{Changes of Bacterial Spectra Presented in Cabbage Heads Inoculated and Non-Inoculated by Xcc}

We showed significant differences in the bacterial spectrum of cabbage heads, in relation to the time point of sampling (before and after storage) and seed inoculation with Xcc. Plants after harvest are generally more vulnerable to infections due to loss of their defense mechanisms against microorganisms [44]. An increase of microbial populations was confirmed by King and Bolin in stored lettuce [45]. Pseudomonas species appeared more on cabbage heads at harvest, however, the bacterial spectrum changed over time in favor of this genus. The decline of other bacterial genera after four months of cold storage was also observed in our previous study [21] and it could be explained by strong antagonistic behavior of Pseudomonas sp. [46] and Bacillus species against other bacteria [47,48].

Bacillus species (i.e., Bacillus subtilis, Bacillus cereus) are widespread in the environment and can be found in soil, foods of plant origin, e.g., grains, vegetables, raw and cooked rice, further in egg white, milk, and meat [49-52]. Spores of Bacillus species can grow and germinate at refrigeration temperatures on different vegetable substrates providing optimal $\mathrm{pH}$ for bacterial growth $[53,54]$. In this study, the presence of the B. subtilis group in control heads was similar in both samplings and detection of the B. cereus group decreased markedly after storage. However, in our previous studies, the increase of the latter genus during storage was observed [21]. Species belonging to Bacillus genera are inconsistently reported as food poisoning microorganisms frequently present in cooked and slowly cooled-down food [55,56], while on the other hand some are considered as potential bio-control agents against postharvest pathogens of vegetables and fruits [48,57].

\section{Conclusions}

The results showed that $\mathrm{Xcc}$, a causal agent of black rot and bacterial soft rot, can survive at $1-2{ }^{\circ} \mathrm{C}$ after four months on Xcc-inoculated cabbage heads. Bacillus and Pseudomonas were the most frequent bacterial genera on cabbage heads. The storage of cabbage heads markedly decreased the diversity of bacterial genera. Pseudomonas species have no considerable effect on Xcc persistence on cabbage heads. 
The B. subtilis group showed an opposite pattern of occurrence on cabbage heads, as compared to Xcc, which will be the subject of further research.

Supplementary Materials: The following are available online at http://www.mdpi.com/2073-4395/10/3/443/s1; Figure S1: Definition of cabbage stalks, inner leaves and superficial leaves; Figure S2: Symptoms on Xcc-inoculated cabbage heads after storage; Figure S3: Symptoms on non-inoculated cabbage heads after storage.

Author Contributions: Conceptualization, A.E., E.P., M.B.; methodology, A.E., J.P., E.P., F.G.; software, L.R.; validation, A.E., M.B. and E.P.; formal analysis, L.R.; investigation, E.P.; resources, F.G.; data curation, L.R., E.P.; writing—original draft preparation, L.R.; writing—review and editing, E.P., A.E., D.G., R.P., M.B.; visualization, L.R.; supervision, A.E.; project administration, J.Č., A.E., M.B.; funding acquisition A.E., M.B., J.Č., R.P. All authors have read and agreed to the published version of the manuscript.

Funding: This work was supported from "Multidisciplinary research to increase application potential of nanomaterials in agricultural practice" (No. CZ.02.1.01/0.0/0.0/16_025/0007314). This research was also supported by the project LTC18009 provided by the Ministry of Education, Youth and Sports of the Czech Republic.

Acknowledgments: The authors thank Pavel Híc, Michael Štencl and Leoš Štencl for the support in controlled storage of cabbage heads and English editing.

Conflicts of Interest: The authors declare no conflict of interest.

\section{References}

1. Coates, L.M.; Johnson, G.I.; Dale, M. Postharvest Pathology of Fruit and Vegetables. In Plant Pathogens and Plant Diseases, 1st ed.; Brown, J., Ogle, H., Eds.; Rockvale Publications: Armidale, Australia, 1997; pp. 533-548.

2. Bhat, K.A. Management of post-harvest Pectobacterium soft rot of cabbage (Brassica oleracea var capitata L.) by biocides and packing material. Afr. J. Agric. Res. 2012, 7, 4066-4074.

3. Bayogan, E.; Jimenez, E.; Boteng, J.; Bautista, O.; Macario, C. Improving Postharvest Cabbage (Brassica oleracea L. var. capitata) Quality Using Alum and Newspaper Wrap. Banwa 2011, 6, 76-86. [CrossRef]

4. Griesbach, E.; Löptien, H.; Miersch, U. Resistance to Xanthomonas campestris pv. campestris (Pammel) Dowson in cabbage Brassica oleracea L. J. Plant Dis. Protect. 2003, 110, 461-475. [CrossRef]

5. Agrios, G.N. Bacterial Soft Rots, 5th ed.; Academic Press: San Diego, CA, USA, 2006.

6. Larka, B.S. Integrated approach for the management of soft rot (Pectobacterium carotovorum sub-sp. carotovorum) of radish (Raphanus sativus) seed crop. Haryana J. Agron. 2004, 20, 128-129.

7. Schaad, N.W.; White, W.C. Survival of Xanthomonas campestris in soil. Phytopathology 1974, 64, 1518-1520. [CrossRef]

8. Dane, F.; Shaw, J.J. Endophytic growth of Xanthomonas campestris pv. campestris on susceptible and resistant host plants in the field environment, detection by bioluminescence. Microb. Releases 1994, 2, $223-229$.

9. Dzhalilov, F.S.; Tiwari, R.D. Soil and cabbage plant debris as infection sources of black rot. Arch. Phytopathol. Plant Protect. 1995, 29, 383-386. [CrossRef]

10. Arias, R.; Nelson, S.; Alvarez, A. Effect of soil-matric potential and phylloplanes of rotation-crops on the survival of a bioluminescent Xanthomonas campestris pv. campestris. Eur. J. Plant Pathol. 2000, 106, 109-116. [CrossRef]

11. Yuen, G.Y.; Alvarez, A.M.; Benedict, A.A.; Trotter, K.J. Use of monoclonal antibodies to monitor the dissemination of Xanthomonas campestris pv. Campestris. Phytopathology 1987, 77, 366-370. [CrossRef]

12. Grimm, R.; Vogelsanger, J. Black Rot Disease on Cabbage, Irrigation and Spreading. In Proceedings of the 7th International Conference on Plant Pathology Bacteria, Budapest, Hungary, 11-16 June 1989.

13. Kocks, C.G.; Zadoks, J.C.; Ruissen, M.A. Spatio-temporal development of black rot (X. campestris pv. campestris) in cabbage in relation to initial inoculum levels in field plots in The Netherlands. Plant Pathol. 1999, 48, 176-188. [CrossRef]

14. Cook, A.A.; Walker, J.C.; Larson, R.H. Studies on the disease cycle of black rot of crucifers. Phytopathology $1952,42,162-167$.

15. Schaad, N.W.; Thaveechai, N. Black rot of crucifers in Thailand. Plant Dis. 1983, 67, 1231-1234. [CrossRef]

16. Farrar, J.; Nunez, J.; Davis, R. Losses due to lenticel rot are an increasing concern for Kern County potato growers. Calif. Agric. 2008, 63, 127-130. [CrossRef] 
17. Miura, K. Shinpen Yasai Engei Handbook. In Vegetable Gardening Handbook, 1st ed.; Nishi, S., Ed.; Yokendo Co. Ltd.: Tokyo, Japan, 2001; pp. 163-173.

18. Mills, A.A.S.; Hurta, R.A.R. Sensitivity of Erwinia spp. to salt compounds in vitro and their effect on the development of soft rot in potato tubers in storage. Postharvest Biol. Technol. 2006, 41, 208-214. [CrossRef]

19. Higashio, H.; Yamada, M. Control of Soft Rot after Harvest of Cabbage in Indonesia. JARQ-Jpn. Agric. Res. Q. 2004, 38, 175-178. [CrossRef]

20. Galati, A.; McKay, A.; Soon, C.T. Minimising Postharvest Losses of Carrots; Farm note No.75/95; Department of Agriculture and Food, Government of Western Australia: South Perth, Australia, 2005.

21. Eichmeier, A.; Peňázová, E.; Pečenka, J.; Čechová, J.; Pokluda, R.; Tekielska, D.; Baránek, M. Rapid Communication. Monitoring the occurrence of bacteria in stored cabbage heads. J. Plant Protect. Res. 2016, 57, 56-61. [CrossRef]

22. Mikiciński, A.; Sobiczewski, P.; Puławska, J.; Malusa, E. Antagonistic potential of Pseudomonas graminis 49M against Erwinia amylovora, the causal agent of fire blight. Arch. Microbiol. 2016, 198, 531-539. [CrossRef]

23. Mondal, K.; Dureja, P.; Prakash Verma, J. Management of Xanthomonas campestris pv. malvacearum-Induced Blight of Cotton Through Phenolics of Cotton Rhizobacterium. Curr. Microbiol. 2001, 43, 336-339. [CrossRef]

24. Wulff, E.G.; Mguni, C.M.; Mortensen, C.N.; Keswani, C.; Hockenhull, J. Biological Control of Black Rot (Xanthomonas Campestris Pv. campestris) of Brassicas with an Antagonistic Strain of Bacillus Subtilis in Zimbabwe. Eur. J. Plant Pathol. 2002, 108, 317-325. [CrossRef]

25. Júnior, T.S.; Silva, J.C.; Gonçalves, R.M.; Soman, J.M.; Passos, J.R.S.; Maringoni, A.C. Survival of Xanthomonas campestris pv. campestris associated with soil and cauliflower crop debris under Brazilian conditions. Eur. J. Plant Pathol. 2020, 156, 399-411.

26. Silva, J.C.; Silva Júnior, T.A.F.; Soman, J.M.; Tomasini, T.D.; Sartori, M.M.P.; Maringoni, A.C. Survival of Xanthomonas campestris pv. campestris in the phyllosphere and rhizosphere of weeds. Plant Pathol. 2017, 66, 1517-1526. [CrossRef]

27. Van der Wolf, J.; Kastelein, P.; da Silva Júnior, T.A.F.; Lelis, F.V.; van der Zouwen, P. Colonization of siliques and seeds of rapid cycling Brassica oleracea plants by Xanthomonas campestris pv. campestris after spray-inoculation of flower clusters. Eur. J. Plant Pathol. 2019, 154, 445-461. [CrossRef]

28. Vicente, J.G.; Holub, E.B. Xanthomonas campestris pv. campestris (cause of black rot of crucifers) in the genomic era is still a worldwide threat to brassica crops. Mol. Plant Pathol. 2013, 14, 2-18. [CrossRef] [PubMed]

29. Roberts, S.; Brough, J.; Hunter, P. Modelling the spread of Xanthomonas campestris pv. campestris in module-raised brassica transplants. Plant Pathol. 2006, 56, 391-401. [CrossRef]

30. Eichmeier, A.; Peňázová, E.; Pokluda, R.; Vicente, J.G. Detection of Xanthomonas campestris pv. campestris through a real-time PCR assay targeting the Zur gene and comparison with detection targeting the hrpF gene. Eur. J. Plant Pathol. 2019, 155, 891-902. [CrossRef]

31. Eichmeier, A.; Baránek, M.; Pidra, M. Analysis of genetic diversity and phylogeny of partial coat protein domain in Czech and Italian GFLV isolates. Plant Protect. Sci. 2010, 46, 145-148. [CrossRef]

32. Chang, C.J.; Donaldson, R.; Crowley, M.; Pinnow, D. A new semiselective medium for the isolation of Xanthomonas campestris pv. campestris from crucifer seeds. Phytopathology 1991, 81, 449-453. [CrossRef]

33. Oliwa-Stasiak, K.; Molnar, C.; Arshak, K.; Bartoszcze, M.; Adley, C. Development of a PCR assay for identification of the Bacillus cereus group species. J. Appl. Microbiol. 2010, 108, 266-273. [CrossRef]

34. Roberts, M.; Nakamura, L.; Cohan, F. Bacillus mojavensis sp. nov., Distinguishable from Bacillus subtilis by Sexual Isolation, Divergence in DNA Sequence, and Differences in Fatty Acid Composition. Int. J. Syst. Bacteriol. 1994, 44, 256-264. [CrossRef]

35. Purohit, H.; Raje, D.; Kapley, A. Identification of signature and primers specific to genus Pseudomonas using mismatched patterns of 16S rDNA sequences. BMC Bioinform. 2003, 4, 19. [CrossRef]

36. Berg, T.; Tesoriero, L.; Hailstones, D. PCR-based detection of Xanthomonas campestris pathovars in Brassica seed. Plant Pathol. 2005, 54, 416-427. [CrossRef]

37. Roohie, R.K.; Umesha, S. Development of multiplex PCR for the specific detection of Xanthomonas campestris pv. campestris in cabbage and correlation with disease incidence. J. Plant Pathol. Microbiol. 2012, 3, 2. [CrossRef]

38. Klindworth, A.; Pruesse, E.; Schweer, T.; Peplies, J.; Quast, C.; Horn, M.; Glöckner, F. Evaluation of general $16 \mathrm{~S}$ ribosomal RNA gene PCR primers for classical and next-generation sequencing-based diversity studies. Nucleic Acids Res. 2012, 41, e1. [CrossRef] [PubMed] 
39. Past 4-The Past of the Future. Available online: http://folk.uio.no/ohammer/past/ (accessed on 13 February 2020).

40. Ter Braak, C.J.F.; Šmilauer, P. Canoco Reference Manual and User's Guide: Software for Ordination (Version 5.0); Microcomputer Power: Ithaca, NY, USA, 2012.

41. Nuñez, A.; Rodríguez, G.; Monteiro, F.; Faria, A.; Silva, J.; Monteiro, A.; Carvalho, C.; Gomes, L.; Souza, R.; de Souza, J.; et al. Bio-based products control black rot (Xanthomonas campestris pv. campestris) and increase the nutraceutical and antioxidant components in kale. Sci. Rep. 2018, 8, 1-11.

42. Ruissen, M.; Vossen, R.; Kocks, C. Growth of Xanthomonas campestris pv. campestris populations at constant and variable temperatures. Neth. J. Plant Pathol. 1993, 99, 173-179. [CrossRef]

43. Mabagala, R.B. Epiphytic bacteria from various bean genotypes and their potential for biocontrol of Xanthomonas axonopodis pv. Phaseoli. Tanz. J. Agric. Sci. 1999, 2, 19-26.

44. Liao, C.; Wells, J. Association of Pectolytic Strains of Xanthomonas campestris with Soft Rots of Fruits and Vegetables at Retail Markets. Phytopathology 1987, 77, 418-422. [CrossRef]

45. King, A.D.; Bolin, H.R. Physiological and microbiological storage stability of minimally processed fruits and vegetables. Food Technol. 1989, 43, 132-139.

46. Afsharmanesh, H.; Ahmadzadeh, M.; Javan-Nikkhah, M.; Behboudi, K. Characterization of the antagonistic activity of a new indigenous strain of Pseudomonas fluorescens isolated from onion rhizosphere. J. Plant Pathol. 2010, 92, 187-194.

47. Zhao, Y.; Li, P.; Huang, K.; Wang, Y.; Hu, H.; Sun, Y. Control of postharvest soft rot caused by Erwinia carotovora of vegetables by a strain of Bacillus amyloliquefaciens and its potential modes of action. World J. Microb. Biot. 2012, 29, 411-420. [CrossRef]

48. Zhao, Y.; Selvaraj, J.; Xing, F.; Zhou, L.; Wang, Y.; Song, H.; Tan, X.; Sun, L.; Sangare, L.; Folly, Y.; et al. Antagonistic Action of Bacillus subtilis Strain SG6 on Fusarium graminearum. PLoS ONE 2014, 9, e92486. [CrossRef] [PubMed]

49. Helgason, E.; Caugant, D.A.; Lecadet, M.M.; Chen, Y.; Mahillon, J.; Lovgren, A.; Hegna, I.; Kvaloy, K.; Kolsto, A.B. Genetic diversity of Bacillus cereus/B. thuringiensis isolates from natural sources. Curr. Microbiol. 1998, 37, 80-87. [CrossRef] [PubMed]

50. Magnusson, M.; Christiansson, A.; Svensson, B. Bacillus cereus spores during housing of dairy cows: Factors affecting contamination of raw milk. J. Dairy Sci. 2007, 90, 2745-2754. [CrossRef] [PubMed]

51. Andersson, A.; Rönner, U.; Granum, P.E. What problems does the food industry have with the spore-forming pathogens Bacillus cereus and Clostridium perfringens? Int. J. Food Microbiol. 1995, 28, 145-155. [CrossRef]

52. Bottone, E.J. Bacillus cereus, a volatile human pathogen. Clin. Microbiol. Rev. 2010, 23, 382-398. [CrossRef]

53. Nicholson, W.; Munakata, N.; Horneck, G.; Melosh, H.; Setlow, P. Resistance of Bacillus Endospores to Extreme Terrestrial and Extraterrestrial Environments. Microbiol. Mol. Biol. Rev. 2000, 64, 548-572. [CrossRef]

54. Valero, M.; Fernández, P.; Salmerón, M. Influence of $\mathrm{pH}$ and temperature on growth of Bacillus cereus in vegetable substrates. Int. J. Food Microbiol. 2003, 82, 71-79. [CrossRef]

55. Brown, K. Control of bacterial spores. Br. Med. Bull. 2000, 56, 158-171. [CrossRef]

56. Daelman, J.; Vermeulen, A.; Willemyns, T.; Ongenaert, R.; Jacxsens, L.; Uyttendaele, M.; Devlieghere, F. Growth/no growth models for heat-treated psychrotrophic Bacillus cereus spores under cold storage. Int. J. Food Microbiol. 2013, 161, 7-15. [CrossRef]

57. Arzanlou, M.; Mousavi, S.; Bakhshi, M.; Khakvar, R.; Bandehagh, A. Inhibitory effects of antagonistic bacteria inhabiting the rhizosphere of the sugar beet plants, on Cercospora beticola Sacc., the causal agent of Cercospora leaf spot disease on sugarbeet. J. Plant Protect. Res. 2016, 56, 6-14. [CrossRef]

(C) 2020 by the authors. Licensee MDPI, Basel, Switzerland. This article is an open access article distributed under the terms and conditions of the Creative Commons Attribution (CC BY) license (http://creativecommons.org/licenses/by/4.0/). 